\title{
Brain, Language, and Linguistics
}

\author{
Victoria A. Fromkin† \\ University of California, Los Angeles
}

During the past quarter of a century, Brain and Language $(B \& L)$ has recorded and stimulated research on the biological/neurological basis for human language. As noted in the Whitaker editorial in the first issue of the first volume (Whitaker, 1974), although for centuries scholars of different disciplines had been interested in the question of brain function and cognition, specifically language, at the time that $B \& L$ was launched there were few linguists that had actively pursued this question. Notable among these few was Roman Jakobson $(1941,1956,1964,1970)$ who was the first linguist to apply linguistic theory to aphasia research. He followed up the views of Badouin de Courtenay (1895) and Ferdinand de Saussure (1879) who had suggested that a study of language pathology could contribute to an understanding of language structure. Jakobson went further stating that "any description and classification of aphasic syndromes must begin with the question of what aspects of language are impaired.' (Jakobson, 1956:239) He despaired over the fact that that "the linguist's contribution to the investigation of aphasia is still ignored" and also believed that "Linguists are also responsible for the delay in undertaking a joint inquiry into aphasia.' Jakobson must have been pleased with the publication of $B \& L$ in 1974, and also with the first lingustics Ph.D. dissertation on language and the brain by the editor of $B \& L$ in 1969, published a few years later as On the Representation of Language in the Human Brain (Whitaker, 1971)., which ushered in the linguistics subarea of neurolinguistics. Unfortunately, it was not until the 1970s, and then only by a few linguists or neurologists deeply interested in linguistic theory (Weigl \& Bierwich, 1970; Whitaker, 1971; Blumstein, 1973, Kean, 1977), did one begin to see serious linguistic involvement in the study of aphasia, and perhaps more importantly, in the study of the brain/ language interface.

A major reason for the linguist's neglect of this key question was the state

†Deceased. 
of linguistics in the United States. The study of the mind (and the brain) was considered by the dominant group of post-Bloomfieldian linguists as outside the scope of the discipline. Bloomfield, the major figure in pre-Chomsky linguistics sharply criticized nonlinguists for "constantly forget[ing] that a speaker is making noise, and credit him, instead, with the possession of impalpable 'ideas", Linguists were advised by Bloomfield "to show, in detail, that the speaker has no 'ideas' and that the noise is sufficient.' (Bloomfield,1926). But even an investigation of the noises produced or comprehended were left to other disciplines to investigate. Bloomfield's aim was a reputable one - to establish a science of linguistics based on objective data subject to empirical verification. It is thus even more unfortunate that his behaviorist views narrowed the kinds of questions linguists were asking.

Despite the misinterpretations that abound regarding Chomsky's view of the importance of brain research, linguistic involvement in brain and language had to wait until he put language back into the mind and the mind into the brain. He was concerned with the answer to the question "What are the physical mechanisms that serve as the material basis for (the) system of (linguistic knowledge) and for the use of this knowledge?' (Chomsky, 1988: 3) Linguists thus became encouraged to turn to research on brain and language by Chomsky's interest in the neural bases of language in keeping with his view that "... we may think of the study of mental faculties as actually being a study of the body . . . specifically the brain . . . conducted at a certain level of abstraction", with the hope that "we (can) discover how these abstract entities are realized in physical mechanisms of a more 'fundamental' nature and how the principles can be grounded in this way." (Chomsky, 1980:31)

The twenty-five years of $B \& L$ attest to how far we have come in integrating linguistic theory into research on the normal and abnormal brain. Before modern technology brought us the new methodologies for studying brain function (MRI, fMRI, MEG, ERP, PET) most studies attempted to understand the normal brain by studying the abnormal brain, e.g., split brains, aphasia, early epilepsy, and hemidecorticates, with some exceptions such as the use of dichotic listening and eye tracking studies. Today, lesion studies and studies of the abnormal brain continue to be of great importance. Undoubtedly, this will continue into the next millennium. But in addition, with the availability of the new noninvasive technologies, more and more studies are dealing with the normal brain. Linguists are playing a major role in this research. Linguists are interested in understanding the nature of language breakdown as well as the kinds of processing of linguistics versus nonlinguistic stimuli in the normal brain. It is no longer enough to categorize an aphasic patient as being agrammatic, one now wants to know for example, not only where the lesions in the brain are localized, and where language is processed for an agrammatic patient, but also the nature of the agrammatism, and how it reveals the organization of the normal mental grammar in the mind and 
brain. Such questions prompted a special three issue volume of $B$ and $L$ (Fromkin, 1995), and will certainly be the basis for other such linguistic and neurological questions in the next millennium. The last part of this millennium has seen the fulfillment of Jakobson's hope. Linguists are now in the "brain business"' since they, like psychologists, neuropsychologists, neurologists, and all cognitive scientists are seeking the answer to the age old and intriguing question of the neurological basis for human language.

\section{REFERENCES}

Bloomfield, L. 1926. A set of postulates for the study of language. Lg. 2, 153-164.

Blumstein, S. 1973. A phonological investigation of aphasic speech. Mouton: The Hague.

Bodouin de Courtenay, J. 1972. In E. Stankiewicz (Ed.), Selected writings of Bodouin de Courtenay. Bloomington: Indiana University Press.

Chomsky, N. 1980 Rules and representations. New York: Columbia Univ. Press.

Fromkin, V. A. (Ed.) 1995. Linguistic representational and processing analyses of agrammatism. Brain and Language, Special Issue, Vol. 50(1-3).

Jakobson, R. 1941. Kindersprache, aphasie und allgemeine lautgesetze. Uppsala: Almqvist u. Wilsells. [Reprinted as Child language, aphasia, and phonological universals 1968. Mouton, The Hague]

Jakobson, R. 1956. Two aspects of language and two types of aphasic disturbances. In R. Jakobson and M. Halle (Eds.), Fundamentals of language. The Hague: Mouton.

Jakobson, R. 1964. Towards a linguistic typology of aphasic impairments. In A. V. S. deReuck and M. O'Connor (Eds.), Disorders of language (pp. 21-41). Boston: Little, Brown.

Jakobson, R. 1970. Toward a linguistic classification of aphasic impairments. In Selected writings II. The Hague: Mouton.

Kean, M. L. 1977. The linguistic interpretation of aphasic syndromes: Agrammatism in Broca's aphasia, an example. Cognition, 5, 9-46.

Saussure, Ferdinand de. 1916. Cours de linguistique generale. Paris: Payot.

Smith, N., \& Tsimpli, I. 1995. The mind of a savant: Language learning and modularity. Oxford and Cambridge: Blackwell.

Weigl, E., \& Bierwisch, M. 1970. Neuropsychology and linguistics: topics of common research. Foundations of Language, 6, 1-18. [Reprinted in Neuropsychology and neurolinguistics: Selected papers Egon Weigle (pp. 40-56). The Hague: Mouton]

Whitaker, H. A. 1971. On the representation of language in the human brain. Edmonton: Linguistic Research, Inc.

Whitaker, H. A. 1974. Editorial. Brain and Language, 1, 1. 